\title{
斜面のレオロジー挙動と疑似地すべり \\ Rheological deformation in slopes and quasi landslides
}

\author{
玉田文吾 ${ }^{a)} \cdot$ 福田順二 ${ }^{a) *} \cdot$ 山本哲朗 ${ }^{b)}$ \\ Bungo TAMADA, Junji FUKUDA and Tetsuro YAMAMOTO
}

\begin{abstract}
Tension cracks often occur on the ground surface of steep slopes after heavy rain. However, the expansion of these cracks does not continue for a long time. This phenomenon of displacement is called a "quasi landslide" because it does not indicate the occurrence of new landslides.

The phenomenon is caused by the rheological deformation of soft clay layers in debris deposits and the increase of shear stress by saturation of the soil near the ground surface results in the deformation. The amount of rainfall, pattern of rainfall and the formation of the slope are closely related to the phenomenon.

By observing this kind of deformation using a tiltmeter within the hole, special landslide prevention measures in the slope are not needed.

Key words : rheology of clay, quasi landslide, tiltmeter within the hole, amount of rainfall

\section{和文要旨}

豪雨後，急斜面の地表面に引張龟裂が発生することがある。しかし，これらの亀裂は長時間にわたって拡大しない。この变位現 像を疑似地すべりと呼称する。なぜならば, これは新規地すべり発生の前兆ではない。

この現象は崩穔土中の複数の軟啠粘土層のレオロジー変形に基づく。これは, 地表面付近の地層の飽和によるせん断応力の增加 が原因である。この原因は，降雨量と雨の降り方および斜面地形が関係する。

この種の変状が孔内傾斜計を用いて確認されたとき，斜面内での特別な地すべり防止対策の必要はない。 キーワード：粘土のレオロジー, 疑似地すべり, 孔内傾斜計, 降雨量
\end{abstract}

\section{1.はじめに}

斜面内に地すべりの前兆と思われる変状が現われるこ とがある。特に地すべり地域内（主として崩積土が滑動 する「堆積層地すべり」タイプを対象とした地域)，あ るいは過去近辺で地すべりが発生した地区では，斜面上 に家屋等があるとき，家屋基礎の龟裂発生，擁壁の開口 龟裂等の変状は住民の不安を増大させる。しかし本文で 対象とした福岡, 大分, 山口各県などでは, 下記の変状 と形態とを見ることが意外に多い。

（1）豪雨を機に地表面に明瞭な引張亀裂などの変状が発 生し, 小規模の表面崩壊が付随することがある。肉眼 観察によると, これらの変状の規模と発生範囲はほと んど拡大しない。

（2）地層（崩積土）の動態観測のために孔内傾斜計等を 設置したとき，豪雨によって一時期変状が発生するが， この変位傾向に地すべりの前兆とは異なる特異の変状 が記録される。

筆者らは以前, 地表面の変状は地すべりの前兆となる ことが多く，これが新規の地すべりに発展する可能性が あることを報告した1)。斜面上に現われた前兆を放置す ることは危険であり，新規地すべりを想定した調查等を 実施することは，地すべりの予防および防災上必要であ る。しかし, 上記(1), (2)については, 新規地すべりの前

\footnotetext{
* 連絡著者/corresponding author

a) 西日本工業大学附屈地盤工学研究所

Geotechnical Research Institute,Nishinippon Institute of Technology ₹ 800-0394 裸岡県京都郡刘田町新津1-11 1-11, Aratsu, Kanda, Miyako, Fukuoka, 800-0394, Japan

b) 山口大学工学部社会建設工学科

Faculty of Engineering.Yamaguchi University
}

兆現象とその一部が類似しているが，前兆とは変状形態 が異なり, 動態観測の結果から見ても変状発生機構が異 なることを示唆している。

新規の地すべり前兆現象に対応する調查，対策につい ては既に述べたことがあるが1)，上記(1)，(2)の変状とその 傾向に対して，有効かつ最小限の経費で対策をたてるこ とは，最近の社会経済情勢から見てきわめて重要である。 本論文はこれらの変状機構を孔内傾斜計の測定結果に 基づいて解析し，これが崩積土内に分布する粘性土の粘 弾性挙動等（レオロジー挙動）であり，この挙動が降雨 による地下水位の変化，さらに特異の地形に関係するこ とを解明した。この粘性土のレオロジー挙動は多くの場 合，新規地すべり発生には至らないことが判ったので， 上記(1)，(2)の変状とその傾向を「疑似地すべり」と呼称 し，疑似地すべりに対する調査方法と対応などについて 言及したものである。

\section{2. 新規地すべり前兆としての変状機構}

崩積土に現われる新規地すべりの前兆の発生機構は次 のようである。

崩積土の堆積過程において, 地盤の沈降作用, 地殼の 変動作用などにより, 崩積土とその下位強風化層の層界 面付近に，地すべり面の素因となる弱面带（潜在すべり 面という）が形成されている地層構造がある。この弱面 帯に，ある量以上の間隙水圧が一定時間以上作用する毎 に，この部分が徐々にクリープせん断破壊する2)。せん 断破壊面が水平方向に対して拡大進行する状態を図 -1 
の模式困として示した1)。

弱面帯内の水平方向の破壊ひずみを $\varepsilon_{s f}$ としたとき，弱 面帯のクリープせん断破壊領域 $\ell_{s f}$ から弱面帯の水平方 向変位量 $\Delta \ell_{s f}$ は,

$$
\Delta \ell_{s f}=\varepsilon_{s f} \cdot \ell_{s f}
$$

によって表示できる。室内実験, テストピット内の現地 試験等から, 水平方向の破壊ひずみの平均的な值は $\varepsilon_{s f}=$ (1.5〜2.0) × $10^{-3}$ 程度が得られている。

例えば $\ell_{s f}=30 \mathrm{~m}$ では,

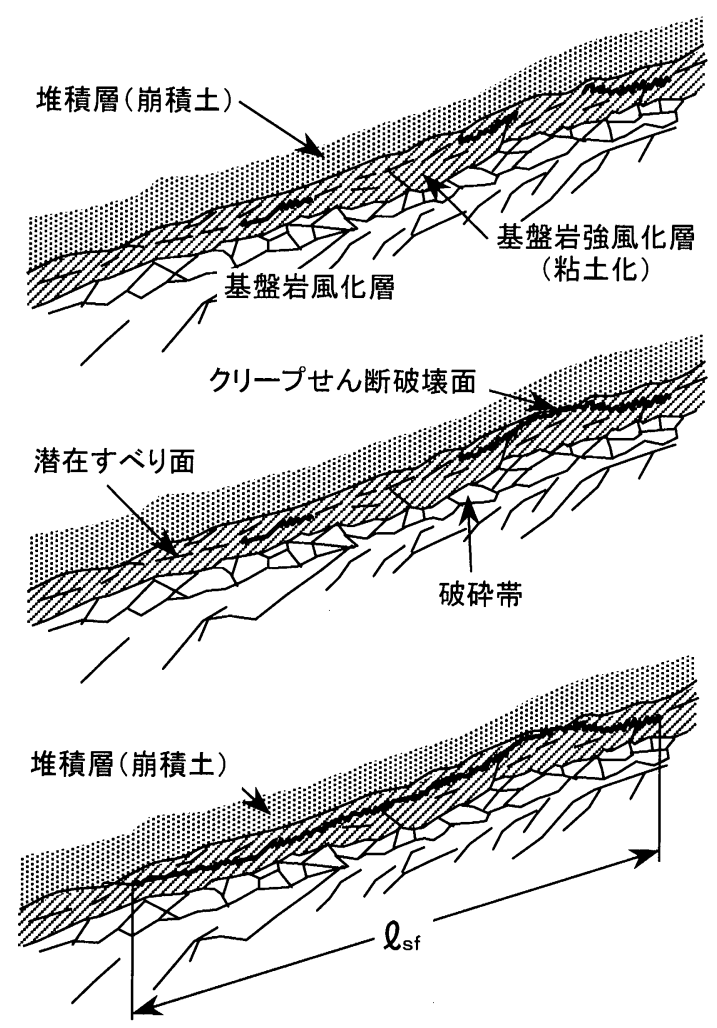

(a)

(b)

図ー 1 潜在すべり面のクリープ破壊領域の拡大

Fig. 1 Progress of range of creep failure in the latent slideface

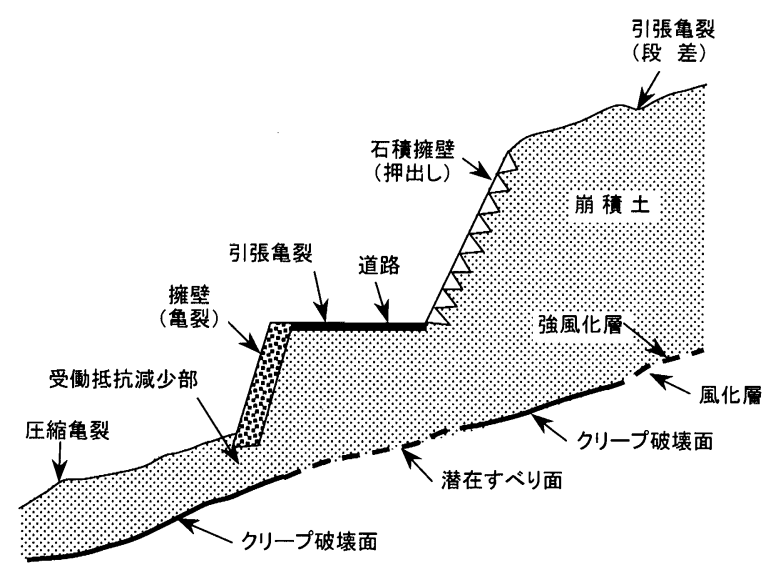

図一2 地表面の変状と地形との関係(潜在域)

Fig. 2 Deformation on ground surface and landform (latent slideface region)

$$
\Delta \ell_{s f}=30 \mathrm{~m} \times(1.5 \sim 2.0) \times 10^{-3}=0.045 \sim 0.060 \mathrm{~m}
$$
の変位量になる。このような水平方向の破壊変位量は図一 2 のように潜在すべり面の受働抵抗の小さい地形または 場所，例えば，急傾斜部が存在する段差地形，石積み擁 壁がある棚田地形，斜面先端部の開放地形等，に見られる。

このとき地表面に現われる変状形態としては，(1)引張・ 圧縮の開口亀裂，(2)小規模の段差亀裂，(3)引張開口亀裂 を伴う部分陥没, (4)石積み擁壁の部分的な押出し, (5) ンクリート擁壁の引張開口亀裂，6小規模の地面隆起等, があり，これらの現象が図ー2のような地形を中心に豪 雨（震度の大きい地震も誘因になるが）ごとに進行して， 変状の範囲と規模とが斜面の上方と下方とに拡大すると, 過去の例から見て新規地すべり発生の「前兆現象」になる。

\section{3. 疑似地すべりの特性と定義}

\section{1 地内の崩積土の地層構造}

変状の内，2 ，(1)，(4)の各変状が長期間にわたり，ほ とんど拡大進行しない状態を「変状の中断現象」という。 中断現象が見られる地内の崩積土の地層構造を図 -3 の 模式図 ${ }^{2)}$ で示したが，次のような特徴がある。

（1）崩積土が形成される過程において，堆積・分級淘汰 両作用によって粘性土層が形成されることがあり，こ れを「運積性粘土層」と呼称する。また上位に次の土 砂が堆積する間の不整合面に沿って風化作用等を伴っ て生成する粘土層を「残積性粘土層」といっている。 これらの多くは含水比が $30 \%$ 超え, 傾斜が $20^{\circ}$ 以上 の軟弱層である。両粘性土共に層厚は不定で，これら が複数の累層構造を呈し, 累計または単層の厚さは 1 $\mathrm{m}$ 以上はある。これらの運積性残積性両粘土層は広範 囲に連続して形成されることはない。

（2）厚い崩積土は不規則な層状構造になり，部分的に転 石，礫層が存在し，これらには地下水が貯留され易い。 平常時でも地下水位が高く, 豪雨の際には一時的に地 下水位の上昇が記録される。変状発生地内には豪雨後 しばらくの間は付近に湧水が見られる。

\section{2 粘性土の調査とせん断強度定数}

崩積土内に分布する粘性土は，変状地内において試錐

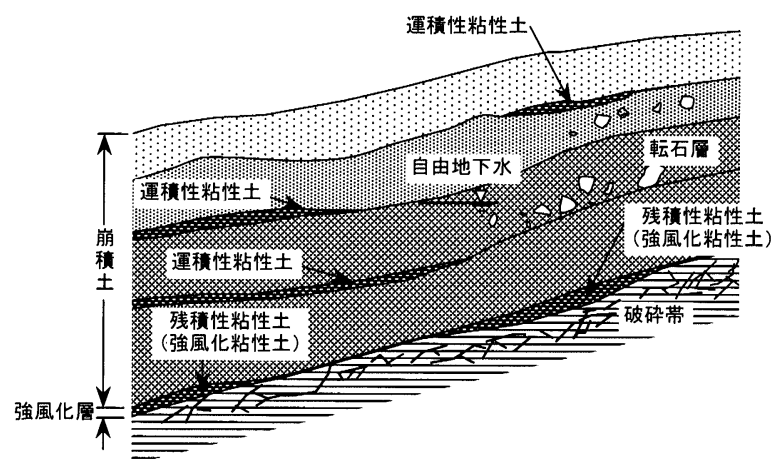

図一 3 崩積土内における粘性土層の模式図

Fig. 3 A type figure of clayey layer in the debris deposit 
（オールコアー方式）を実施すれば，複数の軟弱な粘性 土層として存在が確認できる。しかし, どの部分が滑動 または変形して地表面の変状原因になっているか, せん 断面を検出することができず，地すべり面の位置を特定 することが難しい。

このために地すべり面が含まれると思われる粘性土に ついて, 地すべり発生条件を知るために圧密非排水条件 で一面せん断方式の土質試験を行なった結果では，軟弱 粘性土とはいえ, せん断強度定数は表 - 1 のように大き く2)，この位置でせん断応力（地すべり推力）と間隙水 圧を仮定して計算しても，粘性土自体が簡単にせん断破 壊する状態にはならない。

\section{3 孔内傾斜計による動態観測に見られる特性}

変状はある集中豪雨を機に発生する。地すべり面の位置 を探査する目的で孔内傾斜計を設置し動態観測を行なっ た場合, 測定された変位量に関して下記の特徴が見られる。 (1) 豪雨毎に変位量が記録され，一期間に限って変状が 継続するが，最大変位量はほぼ一定になる。変位量は 地下水位の上昇量と上昇時間に比例し, 降雨量と雨の 降り方に密接な関係がある。このような降雨量と雨の 降り方を「斜面崩壊降雨パターン」というが, このメ カニズムについては詳しい報告をしているので゙, こ こでは省略する。長期間降雨がなく地下水位が低下し た状態では，変位は発生しない。

(2) 変状発生時には変位量は時間の関数となって変化す る。また長期間においては, 変位量曲線が正負の変動 を示すが，負の変位は変位量が回復したことを示す。 (例えば図-22(4)のように)。

\section{表一 1 崩樻土中に分布する粘性土の粘着力, 内部摩擦角}

Table 1 Cohesion and angle of internal friction of clayey layer in the debris deposit

\begin{tabular}{|c|c|c|c|}
\hline 地域 & 地 区 & $\begin{array}{c}C_{2} \\
\left(\mathrm{kN} / \mathrm{m}^{2}\right)\end{array}$ & $\begin{array}{c}\phi_{2} \\
(\mathrm{deg})\end{array}$ \\
\hline \multirow{4}{*}{$\begin{array}{l}\text { 口 } \\
\text { 之 } \\
\text { 津 }\end{array}$} & 富士山 & 16.0 & 27.7 \\
\hline & 富士山 & 20.0 & 23.7 \\
\hline & 大 抜 & 21.0 & 20.2 \\
\hline & 万 詰 & 24.0 & 12.5 \\
\hline \multirow{4}{*}{$\begin{array}{l}\text { 油 } \\
\text { 谷 }\end{array}$} & 角 山 & 14.0 & 26.3 \\
\hline & 平 野 & 17.0 & 25.5 \\
\hline & 白 木 & 21.0 & 15.3 \\
\hline & 油谷島 & 18.0 & 10.3 \\
\hline \multirow{5}{*}{ 北 } & 元 触 & 23.0 & 20.2 \\
\hline & 血 山 & 26.0 & 24.3 \\
\hline & 船唐津 & 19.0 & 28.2 \\
\hline & 中 尾 & 29.0 & 19.4 \\
\hline & 大 塔 & 17.0 & 25.8 \\
\hline \multirow[t]{3}{*}{ 松 } & 田 原 & 16.0 & 30.7 \\
\hline & 筒 井 & 21.0 & 18.5 \\
\hline & 赤 木 & 15.0 & 31.5 \\
\hline
\end{tabular}

※ $c_{2}, \phi_{2}$ は圧密非排水試験による
（3）このような孔内傾斜計の変状は，図－4のような段 差地形（先端解放地形）において, 崩積土部分の受働 抵抗が小さく，運積性粘土または残積性粘土が存在す る地内に設置された孔内傾斜計に見られるので, 同一 地内でも設置場所によって異なった変位量曲線になり 地形と地層構造との影響が大きい。

\section{4 疑似地すべりの特性と定義}

運積性 - 残積性両粘土層以外の崩積土は, せん断強度 定数が表 - 1 の数值よりもはるかに大きいので, 両種粘 土層と崩積土とを含む連続したせん断破壊面（地すべり 面）は発生しない。このため変状が主として粘土層自体 の粘弾性変形などに留まるとき，これが先に述べた変状 中断の原因になる。

この場合, 地表面で見られる変状は新規地すべりの前 兆にはならないので，これを「疑似地すべり」と呼称す る。特に粘性土の粘弾性挙動を許容する地形（例えば図 -4）と地下水位の変化をもたらす降雨量および雨の降 り方が重要な条件になる3”。ここで疑似地すべりを「崩 積土中または下位の風化層層界面上位付近に部分的に分 布する軟弱粘性土において，これ自体またはこれら上部 崩積土のレオロジー挙動が地表面に現われる変状であ

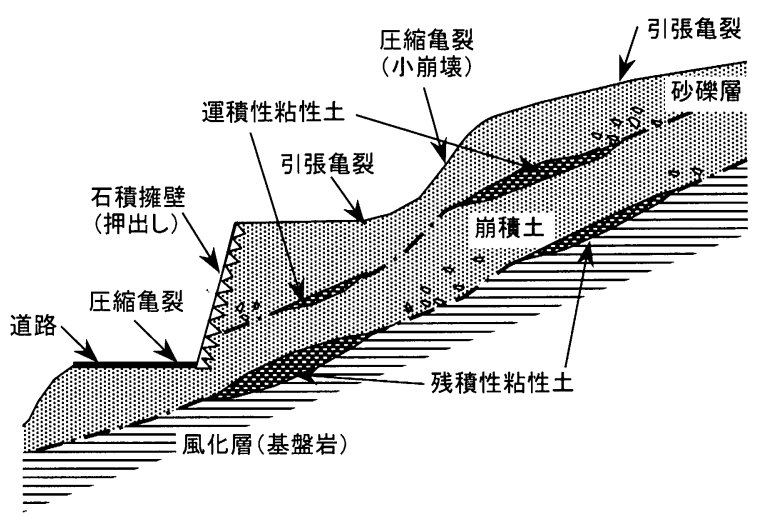

図-4 疑似地すべり地区の粘性土の地層構造と地形(模式図)

Fig. 4 Structure of clayey layer in quasi landslide area and landform (a type fig.)

表一 2 地すべりと疑似地すべりとの変状機構の比較 Table 2 Comparison of landslide and quasi landslide for the mechanism of deformation

\begin{tabular}{|c|c|c|}
\hline 変状·機桠 & 地すべり & 疑似地すべり \\
\hline 変状機粠 & 一面せん断形式のクリープ破壊 & 粘性土のせん断歪み \\
\hline 変形面 & 潜在域すべり面内の単啗面 & 崩積土内粘性土での複数面のことがある \\
\hline 変形形態 & 水平方向歪みの累鄱変位至 & 一部の回復を伴う粘弾性変形 \\
\hline 地表面の変状範囲 & 範囲および角裂の拡大進行 & 地形に関係し，限定された範囲 \\
\hline 変状の原因 & 単㽫面内の有効応力の低下 & 降雨による地表面付近の地層の飽和 \\
\hline 影響地下水 & 自由地下水·被圧地下水 & 自由地下水(漫透水) \\
\hline 平常時の地下水位 & 低い & 高い \\
\hline 変状部分の厚さ·傾斜 & 超薄層 $(1 \sim 2 \mathrm{~mm}) \cdot 15 \sim 20^{\circ}$ & 厚層 $(1 \mathrm{~m}$ 以上 $) \cdot 25 \sim 30^{\circ}$ \\
\hline
\end{tabular}


る。と定義する。表 -2 に新規地すべりの変状機構と 疑似地すべりの変状機構との差異を示した。

\section{4. 粘性土の粘性係数の室内測定}

\section{1 一軸スライスせん断方式}

崩積土のレオロジー挙動を解析するには，粘土層の粘 性係数が必要になる。測定は図-5 の一軸圧縮スライス せん断方式を用いた。(1)は直径 $50 \mathrm{~mm}$ ，平均高さ $100 \mathrm{~mm}$ のモルタル柱で一端が水平面と $\theta=30^{\circ}$ をなす楕円断面 積Aの面になる。(2)粘性土である。一軸圧縮試験装置 の加圧板(4)と上部モルタル柱との間には(3)のスラストベ アリングがあり，上部モルタル柱が水平方向にスムース に移動する機能を持つ。

粘性土の粘性係数りは，これが粘性流動するとき，図 - 6 の準ニュートン流体挙動をするとすれば，せん断応 力 $\tau$ との間に, $r$ をせ断歪み, $t$ を時間として,

$$
\tau=\eta \cdot d r / d t
$$

の関係がある。さらに図ー 7 の関係から，試料の厚さを $h(=6 \sim 8 \mathrm{~mm})$ とし, $x$ をせん断方向の変位量, $y$ を鉛

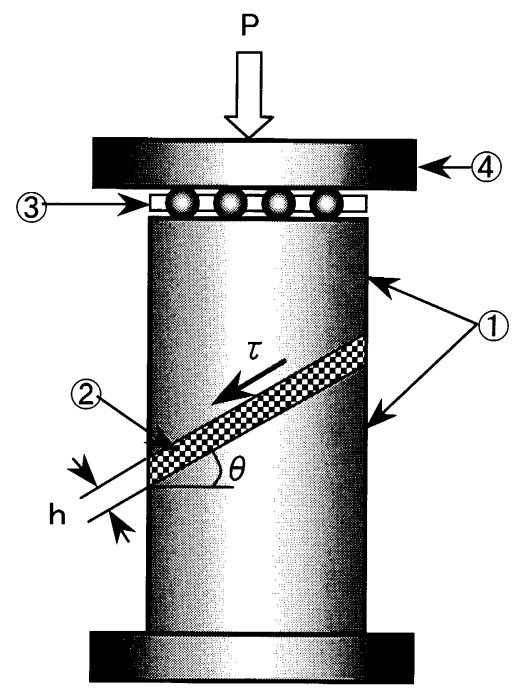

図－5－軸圧縮スライス方式粘性係数測定装置

Fig. 5 Measured apparatus of coefficient of viscosity (Unconfined compressive slice method)

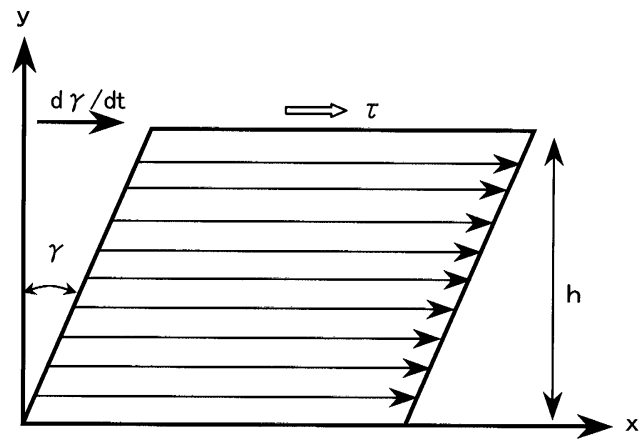

図一 6 粘性土のせん断変形

Fig. 6 Shearing deformation of cohesive soil
直方向の変位量とすれば, $\gamma=(y / \sin \theta) /(h / \cos \theta)$ の関 係から，

$$
\gamma=y /(h \cdot \tan \theta)
$$

ここで，式(3)の両辺を $t$ につて微分すると，

$$
d \gamma / d t=\{1 /(h \cdot \tan \theta)\} \cdot d y / d t
$$

式(4)から上部モルタル柱の沈下速度 $d y / d t$ が判明すれ ば，粘性係数クが測定できる。この方法では，上下部モ ルタル柱と粘性土との間に摩擦板（摩擦板としてはサン ドペーパー等を使用）を挿入するが，多くの試料では含 水比が50\%以上でないと上部モルタル柱だけがスリップ して図ー6の流動形態にならず粘性係数クが求まらない。

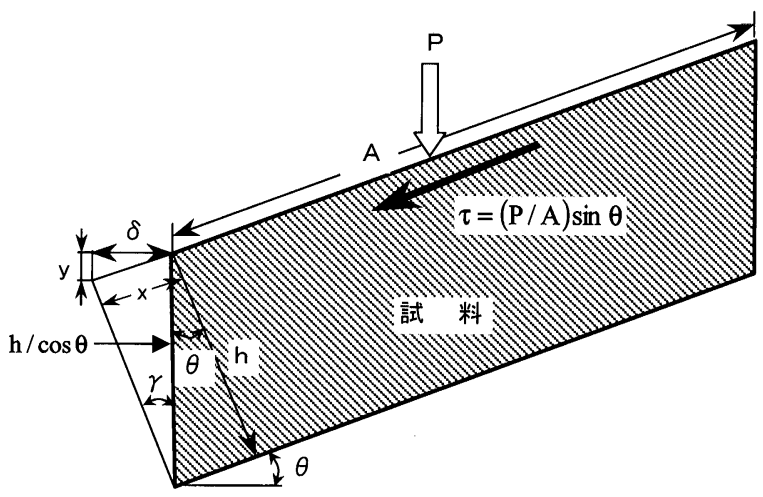

図ー7一軸スライス試験における試料のせん断変形

Fig. 7 Shearing deformation of cohesive soil sample on the apparatus

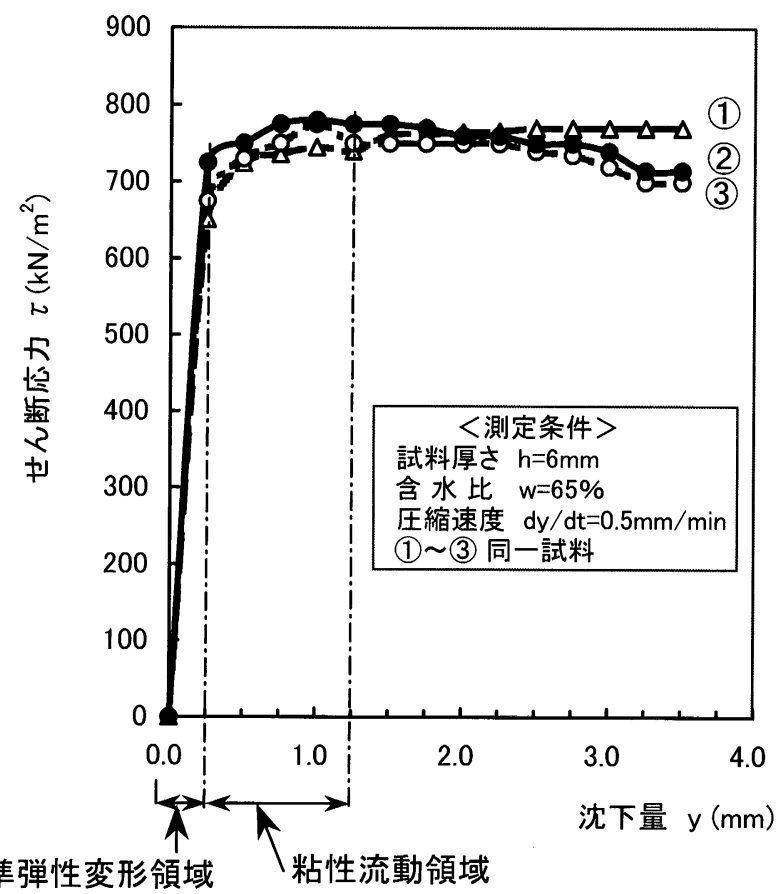

図一8一軸スライス試験におけるせん断応力と沈下量との 関係

Fig. 8 Relation between shearing stress and settlement 
試料のせん断応力 $\tau$ は,

$$
\tau=(P / A) \sin \theta
$$

とし，楕円断面積 $A$ は下記の補正を行なう。

$$
A=\pi a(b-y / \sin \theta)
$$

ここで， $a$ は短軸半径， $b$ は長軸半径の各長さである。 図 -8 は, 試験過程でのせん断応力 $\tau$ と沈下量 $y$ との関 係を測定した一例であるが，この曲線は準弾性領域と粘 性流動領域とに分けられ，粘性係数の計算は粘性流動領 域の数值から求める。この測定法は採取試料の含水比の. 調整（加水攪乱して，これを正規圧密したものが試験試 料になる）と摩擦板の種類の決定が重要であり, 試験方 法は簡単ではなく試行が要る。

\section{2 粘性係数・落下回数と含水比との関係}

図－9は粘性土の液性限界を求めるための流動曲線と, 粘性係数 $\eta$ と試料含水比 $w$ との関係を対比した一例（5.1 で述べる福岡県下の粘性土）である。同一試料では粘性 係数と含水比との間には,

$$
\eta=\eta_{0} \cdot \exp (-\beta w)
$$

の実験式が得られ(4)，一方，流動曲線における落下回数 $N$ と含水比 $w$ との間には,

$$
N=N_{0} \cdot \exp (-\beta w)
$$

\section{表一 3 室内実験による粘性係数の測定}

Table 3 Coefficient of viscosity of cohesive soil by the unconfined compressive slice method

\begin{tabular}{|c|c|c|}
\hline 地 区名 & $\begin{array}{c}\text { 含水比 } \\
(\%)\end{array}$ & $\begin{array}{c}\text { 粘性係数 } \\
\left(\mathrm{kN} \cdot \mathrm{s} / \mathrm{m}^{2}\right)\end{array}$ \\
\hline 美 祢(山口) & 54.05 & $1.10 \times 10^{6}$ \\
\hline 湯 平 (大分) & 59.14 & $0.92 \times 10^{6}$ \\
\hline 星 野(福岡) & 55.24 & $1.98 \times 10^{6}$ \\
\hline
\end{tabular}

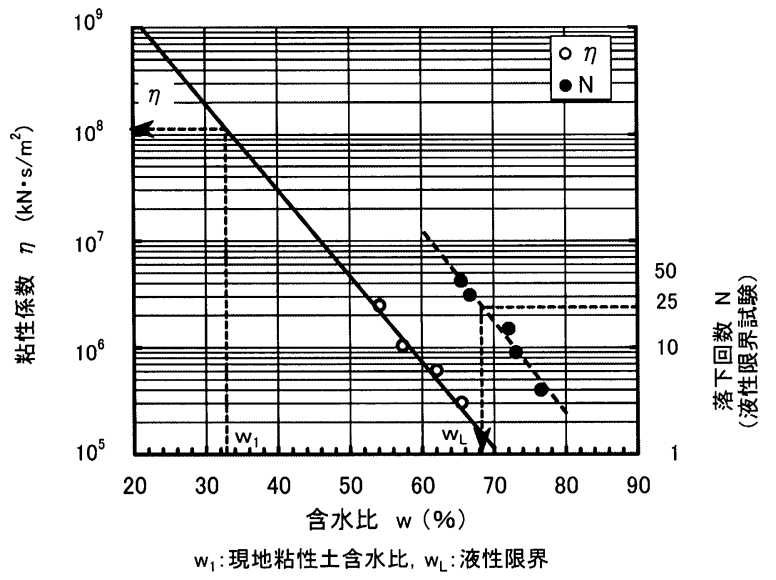

図-9 粘性係数・落下回数と含水比との関係

Fig. 9 Relation between coefficient of viscosity, number of drop and moisture content
の関係がある。 $\eta_{0}$ 及び $N_{0}$ は $w=0$ における,$N$ のそれ ぞれの值であるが，指数 $\beta$ はほほ同じであるため，式(7) と式(8)とは平行の直線で示される特性がある ${ }^{4)} 。$

さきにこの方式の土質試験は，粘性土の含水比が $50 \%$ 以上が条件になると述べた。しかし現地の粘性土の含水 比はこれよりも小さいので, 粘性土の流動曲線を求め, さらに4.1の方法でクを测定しておくと，図－9の方法に よって現地粘性土の含水比 $w_{1}$ に対応する粘性係数 $の$ 近 似值が間接的に求まるので，当面この方式を提案したい。

表一 3 は, 室内試験可能な含水比のもとで測定した粘 性係数である。

\section{3 クリープせん断方式}

以上の試験方法では，せん断弾性係数が求まらない。 このために図ー10の一面せん断方式のクリープ試験を 行った5)。これは一定のせん断応力 $\tau_{0} を$ 加えて，図-11 のせん断歪みの時間的変化を測定すると，5.1で述べる 粘性土の粘弾性挙動からせん断弾性係数と粘性係数とが 測定できる。しかし，この方法も上限降伏值以内で $\tau_{0}$ をどの程度にするかなどの試行を要する煩雑性がある。 室内試験からレオロジー定数を測定するには $4.1 ４ .2$ お よび4.3で述べた上記二種類の方式を併用した。

\section{5. 孔内傾斜計による粘性土層の粘性係数測定}

\section{1 粘性土の粘弾性挙動}

図－12は福岡県下の地すべり指定地区一部の地内にお ける孔内傾斜計の挙動の時間変化を示したものである。 この地内の地形概略断面図は図－13のようになっており， 地層は基盤岩の風化凝灰角磁岩上に堆積した崩積土であ

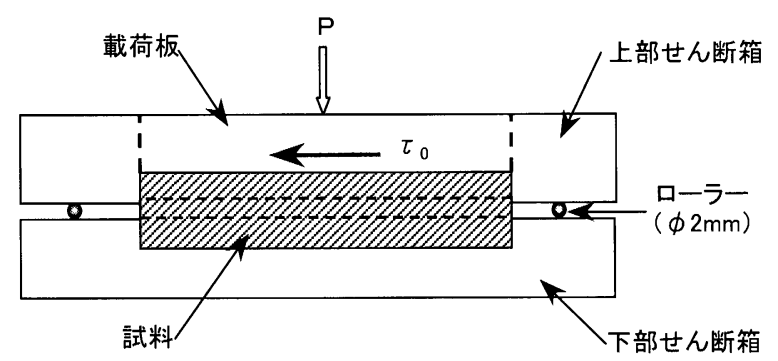

図一10 一面せん断方式の粘性係数測定方法

Fig. 10 Measured apparatus of coefficient of viscosity (direct shear method)

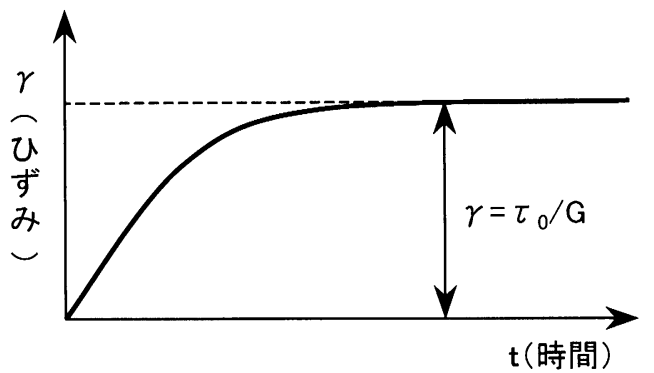

図一11粘性土せん断ひずみの時間的変化(模式図)

Fig. 11 Relationships shearing strain of clayey soil versus lapse time (a type fig.) 
る。崩積土内には平均含水比 $32.60 \%$ の運積性粘土層（飽 和粘土） が $30^{\circ}$ の角度で分布し，地表面には宅地付近な どに引張亀裂が見られる。先端開放地形であり，不安定 斜面の一つとして動態観測が実施された。

孔内傾斜計の挙動は 6 月の雨期に入ってから顕著に なったが，粘性土(変形区間) は約 $1 \mathrm{~m}$, 変位量は約 1 ケ 月間で $0.02 \mathrm{~m} ，$ 女ん断歪みは $0.02(=0.02 / 1)$ である。

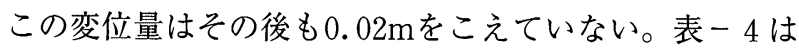
せん断歪み速度 $d r / d t$ （測定期間の平均值として）の 時間変化を求めたものである。これからせん断歪み速度 を縦軸（対数目盛），時間 $t$ を横軸（算術目盛）にプロッ トしたものが図-14で，図中，横方向の太線は表－4の $t$ を示す。

室内実験によると粘性土に一定量のせん断応力 $\tau_{0}$ を 加えると, せん断歪み $\gamma$ の時間 $t$ に対する変化は図 -11 のようになる。ここで，Gをせん断弾性係数として挙動 をスプリングの模型で表し, 粘性係数りをダッシュポッ トの模型で示すと, 図ー11の曲線は図-15のレオロジー 模型で挙動を表示することができる。このスプリングと ダッシュポットの並列模型 (Voigt modelと言われてい る）のせん断応力 $\tau_{0}$ は, 両模型をせん断させる応力の

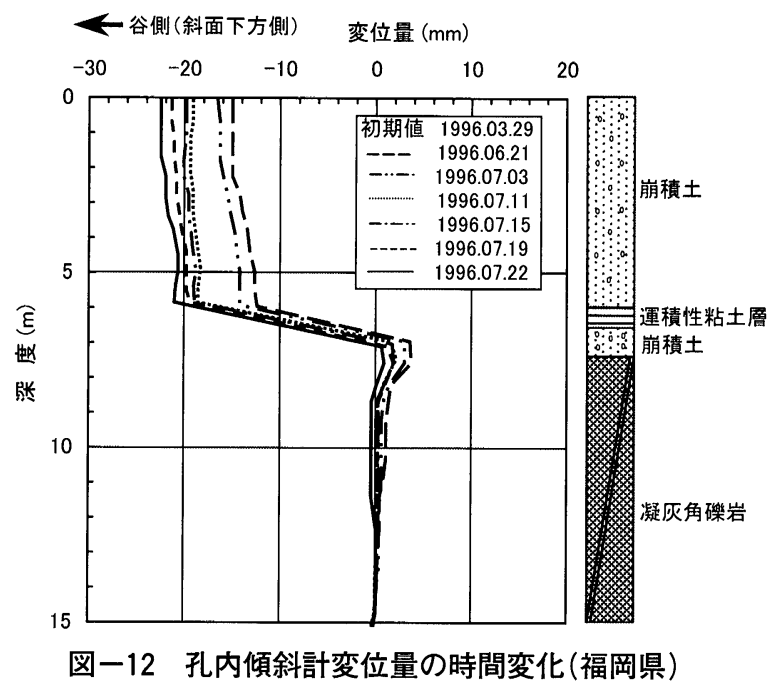

Fig. 12 Measurement of displacement of clayey layer used tiltmeter within the hole(Fukuoka Pref.)

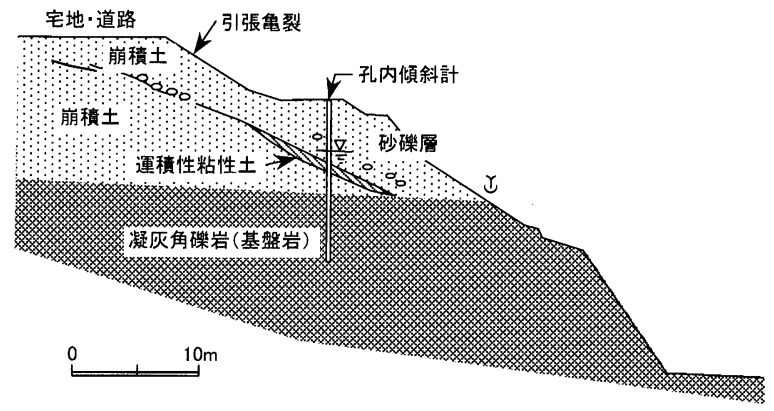

図一13 変位量測定地内の地層断面図 (福岡県)

Fig. 13 Geological section near the tiltmeter within the hole(Fukuoka Pref.)
和になるので，

$$
\tau_{0}=G \gamma+\eta(d \gamma / d t)
$$

これから

$$
d \gamma / d t+G \gamma / \eta=\tau_{0} / \eta
$$

の線形微分方程式になるから， $\eta, G ， \tau_{0}$ が一定として，

$$
\gamma=\tau_{0} / G\{1-\exp \cdot(-G \cdot t / \eta)\}
$$

が得られる。

式(11)を時間 $t$ に関して微分すると，

$$
d \gamma / d t=\left(\tau_{0} / \eta\right) \exp (-G \cdot t / \eta)
$$

表一4 せん断歪み速度と経過時間との関係(福岡県)

Table 4 Relationships of velocity of shearing strain versus lapse time (Fukuoka Pref.)

\begin{tabular}{|c|c|}
\hline $\begin{array}{c}\mathrm{d} \gamma / \mathrm{dt} \\
\times 10^{-3}\left(\mathrm{day}^{-1}\right)\end{array}$ & $\begin{array}{c}\mathrm{t} \\
(\mathrm{day})\end{array}$ \\
\hline 1.778 & $0 \sim 6$ \\
\hline 0.965 & $6 \sim 10$ \\
\hline 0.514 & $10 \sim 18$ \\
\hline 0.214 & $18 \sim 26$ \\
\hline
\end{tabular}

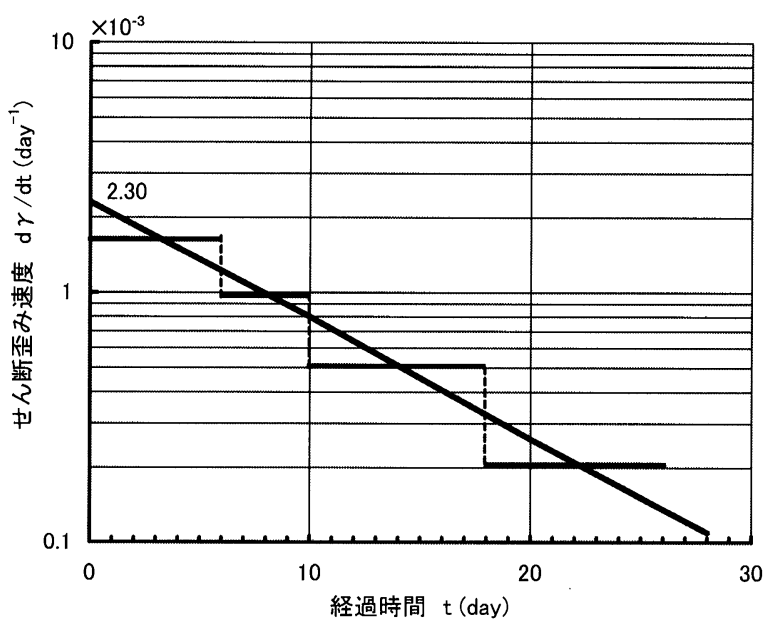

図一14 せん断歪み速度 $d \gamma / d t$ の時間変化 (福岡県)

Fig. 14 Relation between velocity of shearing strain and time proceeds (Fukuoka Pref.)

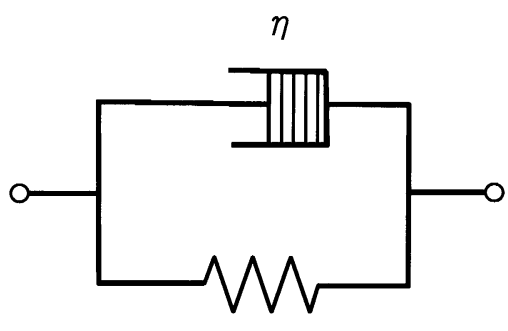

G

図一15 粘弾性変形のレオロジーモデル

Fig. 15 Rheological model of viscoelastic deformation 
になるが，この $d r / d t-t$ 曲線は片対数方眼紙では直線 で表される。図ー14は測定された粘性土の挙動が近似的 にVoigt modelになることを示している。

図－14から $d r / d t$ の時間変化の測定式は次のようになる。

$$
\begin{aligned}
& d \gamma / d t=2.3 \times 10^{-3} \exp (-0.11 t) \quad\left[\mathrm{day}^{-1}\right] \\
& =2.66 \times 10^{-8} \exp \left(-1.27 \times 10^{-6} t\right) \quad\left[\mathrm{s}^{-1}\right] \cdots \cdots(13) \\
& \tau_{0} / G=\left(\tau_{0} / \eta\right) /(G / n)=2.66 \times 10^{-8} / 1.27 \times 10^{-6}=0.021 \\
& \gamma=0.021\left\{1-\exp \left(-1.27 \times 10^{-6} t\right)\right\}
\end{aligned}
$$

これが孔内傾斜計で測定された粘性土の粘弾性挙動を 示す式である。粘性土のレオロジー挙動は, せん断応力 がある值 $f$ 超えた時点で発生するもので, 塑性流動を 示すスラーダー模型も重要である。この $f$ 現地測定 データから解析するには, 孔内傾斜計と地下水位計とを 自動観測方式にすると解明される可能性があるが，現段 階ではスライダーをレオロジーモデル中に組込むまでに 至っていない。

\section{2 粘弾性挙動の機構と粘性係数}

降雨によって粘性土の粘弾性挙動が発生する理由は, 地下水位上昇による粘性土上部地層の飽和に伴う斜方分 力の増加である。

この地内の粘性土以外の崩積土の物理的性質の平均值 は, 間隙比 $e=1.00$, 飽和度 $S_{r}=65.0 \%$, 土粒子密度 $\rho_{s}$ $=2.65 \mathrm{~g} / \mathrm{cm}^{3}$, 含水比 $w=25 \%$, 湿潤単位体積重量 $\gamma_{t}=$ $16.56 \mathrm{kN} / \mathrm{m}^{3}$, 乾燥単位体積重量 $\gamma_{d}=13.25 \mathrm{kN} / \mathrm{m}^{3}$, 飽 和単位体積重量 $\gamma_{s a t}=18.25 \mathrm{kN} / \mathrm{m}^{3}$ が得られている。この ため降雨によって地表面まで飽和した場合に斜方分力の 增加は, 平常時の地下水位から判断して, 崩積土の飽和 部分の範囲は図ー13に示したように深度 $4 \mathrm{~m}$ 程度の間に なり，同図で示すように粘性土の分布長 $10 \mathrm{~m}$ ，傾斜 $30^{\circ}$ であるから，

不飽和： $(16.56 \times 4+18.25 \times 2) \times 10 \cdot \cos 30^{\circ} \cdot \sin 30^{\circ}$ $=444.9 \mathrm{kN} / \mathrm{m}$

飽 和： $(18.25 \times 6) \times 10 \cdot \cos 30^{\circ} \cdot \sin 30^{\circ}=474.1 \mathrm{kN} / \mathrm{m}$ になり，斜方分力で $30 \mathrm{kN} / \mathrm{m}$ 程度，せん断応力では $3 \mathrm{kN}$ $/ \mathrm{m}^{2}$ の僅かな応力増加になる。これで粘性土の粘弾性変 形が起こったとすれば，粘性土の粘性係数りとせん断弾 性係数 $G$ は,

$$
\begin{aligned}
& \tau_{0} / \eta=3 / \eta=2.66 \times 10^{-8}, \quad \eta=1.13 \times 10^{8} \mathrm{kN} \cdot \mathrm{s} / \mathrm{m}^{2} \\
& G / \eta=1.27 \times 10^{-6} \mathrm{~s}^{-1}, \\
& G=1.27 \times 10^{-6} \times 1.13 \times 10^{8}=144 \mathrm{kN} / \mathrm{m}^{2}
\end{aligned}
$$

の值である。これらの数值のうちクは図-9の室内試験 結果と近似的に一致する。得られたレオロジー定数と粘 弾性挙動については次のように考察できる。

(1) 粘性係数》は粘性土としては中程度以上の值である が，せん断弾性係数はかなり小さい值になっている。 粘弾性挙動をする場合, せん断弾性係数が低下するこ とが流動の条件になるのではないか。しかしク $=10^{8} \mathrm{kN}$ ・ $\mathrm{s} / \mathrm{m}^{2}$ のオーダーでは粘弾性挙動は間もなく終息する。

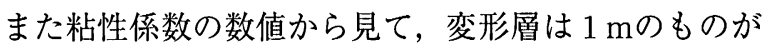
均等なせん断歪みを持つのではなく，層全体として平 均的な粘性係数である（例えば図-24）。なお，孔内 傾斜計付近の引張亀裂は1996年以降ほとんど変化して いない。

（2）粘性土は，図－4あるいは図－13に示したような急 傾斜，先端開放地形等の条件が揃うと意外にも小さい せん断応力で粘弾性挙動を開始すると考えられる。こ のため降雨による地下水位の上昇と地表面付近の崩積 土の飽和は, この状態がある時間持続すると, 粘性土 の粘弾性挙動の原因になる。すなわち地表面付近が飽 和するための降雨量と雨の降り方は重要な要因になる が $^{3)}$ ，この地内の測定期間の降雨量は 6 月中旬 $399 \mathrm{~mm}$

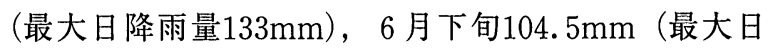
降雨量45mm）の降り方であった。

\section{6. 粘性土のせん断歪み回復挙動の観測}

\section{1 せん断歪みの回復挙動の測定}

山口県美祢市において，図－16の地形概略図に示すよ うに斜面肩側にある市道の一部に引張龟裂と小陥没現象 が発生したので動態観測のために孔内傾斜計を設置し測 定を開始した。測定斜面は風化花崗閃緑岩を基盤岩とし， この上位には層厚不定の崩積土がある。孔内傾斜計付近 では傾斜 $20^{\circ}$ 程度の，層厚 $1 \mathrm{~m}$ 程度，平均含水比 $36.54 \%$ の運積性・残積性両粘性土(飽和粘土)が部分的に発達し ている。図-17は変位量の測定結果である。連続累計降 雨量が350〜 400mmになると地下水位の上昇と変位とが 観測されるので，横孔排水ボーリングを施工したが工事 が完了し，暫らくしてから図－18のような変位回復の時 間変化が測定された。ここでは特異な現象として変位量 の回復はかなり詳しく測定されている6)。表 -5 は観測 結果であり，これから回復せん断歪み $\gamma^{\prime}$ の時間変化 $d \gamma^{\prime}$ $/ d t$ と経過時間 $t$ との関係，すなわち $d \gamma^{\prime} / d t-t$ を求めた ものが図ー19である。粘性土層の厚さ $1 \mathrm{~m}$, 回復変位量 $0.0125 \mathrm{~m}$, 回復せん断歪み $\gamma^{\prime}=0.0125(=0.0125 / 1)$ が測定 された。孔内傾斜計設置以降のせん断歪みを $\gamma_{0}$ とすれば,

$$
\gamma=\gamma_{0}-\gamma^{\prime}
$$

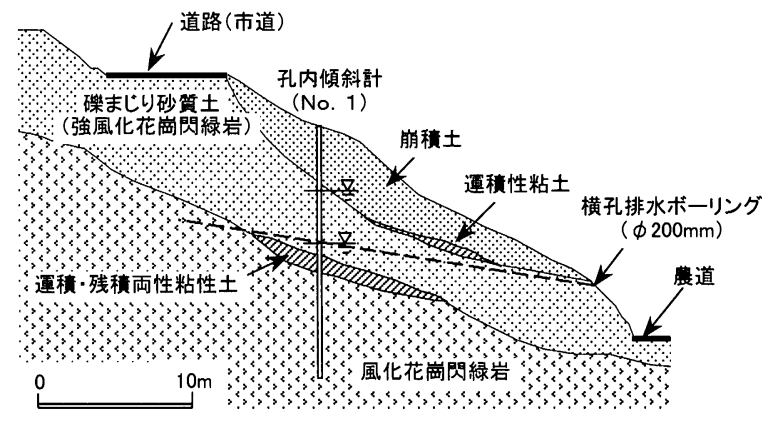

図一16 孔内傾斜計付近の地層断面図 (山口県美祢市)

Fig. 16 Geological section near the tiltmeter within the hole (Yamaguchi Pref.) 
回復せん断歪みはVoigt modelにおいて除荷したときに 見られるので，除荷による回復せん断歪み $\gamma^{\prime}$ (減少量) は 減少応力をでしたとき次のようになる。

$$
\gamma^{\prime}=\tau^{\prime} / G\{1-\exp (-G \cdot t / \eta)\}
$$

式(16)を式(15)に代入して，こ水を時間 $t$ について微分する と,

$$
\begin{aligned}
& r=\gamma_{0}-\left(\tau^{\prime} / G\right)\{1-\exp (-G \cdot t / \eta)\} \\
& d \gamma / d t=-\left\{\left(\tau^{\prime} / \eta\right) \exp (-G \cdot t / \eta)\right\}
\end{aligned}
$$

$d r / d t-t$ の関倸は，負の記号を除けば式(12)と同形式に なる。表－5の現場測定值から図ー19の測定式が得られ るが,これによると $t \leqq 35$ dayに打いて

$$
\begin{aligned}
d \gamma / d t & =-\left\{1.20 \times 10^{-3} \exp \left(-1.20 \times 10^{-6} t\right)\right\}\left[\mathrm{day}^{-1}\right] \\
& =-\left\{1.39 \times 10^{-8} \exp \left(-1.20 \times 10^{-6} t\right)\right\} \quad\left[\mathrm{s}^{-1}\right]
\end{aligned}
$$$$
\gamma^{\prime}=0.016\left\{1-\exp \left(-1.20 \times 10^{-6} t\right)\right\}
$$

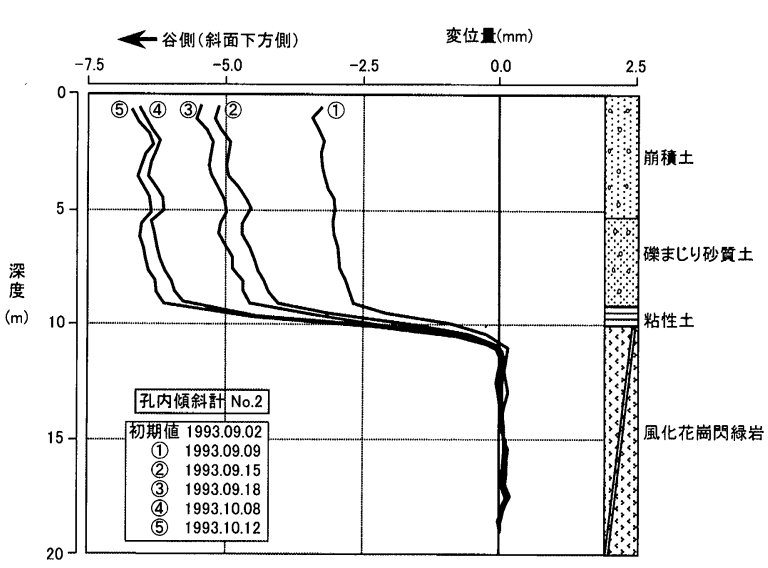

図一17 孔内傾斜計による変位量測定結果 (山口県美祢市)

Fig. 17 Measurement of displacement of clayey layer used tiltmeter within the hole(Yamaguchi Pref.)

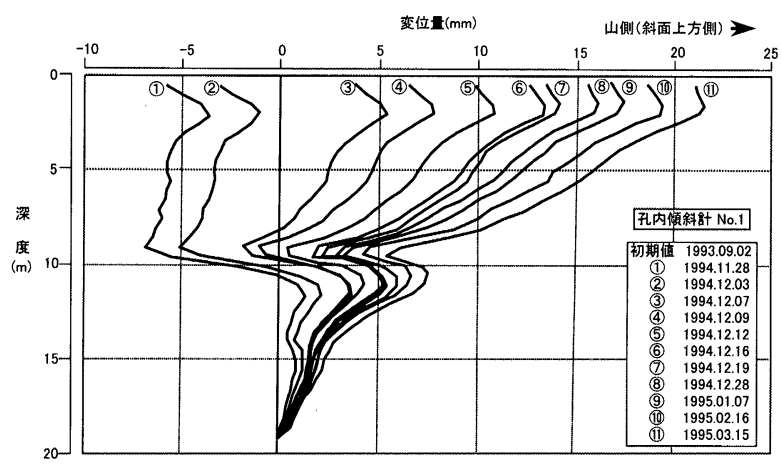

\section{図一18 孔内傾斜計による変位量回復の時間的変化 (山口県美祢市)}

Fig. 18 Measurement of displacement ( recovery) of clayey layer used tiltmeter within the hole (Yamaguchi Pref.)
これを式(14)の数値および指数を比較すると，測定箇所 が異なるうえ, 式(19)の場合はこれが回復歪みにもかかわ らず両者の傾向と数值はよく似ている。

\section{2 回復過程における機構とレオロジー定数}

図一19の場合, 地下水排除工事によって地下水位が低 下したことがせん断歪み回復の要因である。本地内では, 乾期と相俟って地下水排除工事によって地下水位が $3 \mathrm{~m}$ 程度低下したため（図－16参照）せん断応力の減少は,

飽 和 時: $18.25 \cdot 3 \cdot \cos 20^{\circ} \cdot \sin 20^{\circ}=17.6 \mathrm{kN} / \mathrm{m}^{2}$

水位低下時 $: 16.65 \cdot 3 \cdot \cos 20^{\circ} \cdot \sin 20^{\circ}=16.1 \mathrm{kN} / \mathrm{m}^{2}$ から $1.5 \mathrm{kN} / \mathrm{m}^{2}$ である。なお崩積土の物理性質は 5.2 と同 じと仮定した。Voigt modelにおける除荷（応力減少）に よる回復せん断歪み $\gamma^{\prime}$ からせん断弾性係数と粘性係数と を計算すると，

$$
\begin{aligned}
& \tau^{\prime} / \eta=1.50 / \eta=1.39 \times 10^{-8}, \quad \eta=1.08 \times 10^{8} \mathrm{kN} \cdot \mathrm{s} / \mathrm{m}^{2} \\
& G / \eta=1.20 \times 10^{-6} \mathrm{~s}^{-1}, \\
& G=1.20 \times 10^{-6} \times 1.08 \times 10^{8}=130 \mathrm{kN} / \mathrm{m}^{2}
\end{aligned}
$$

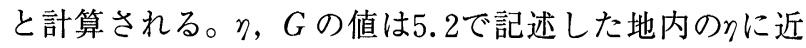
いものになっている点が注目される。

図ー13抢よび図ー16に示したように，レオロジー挙動 は飽和粘性土の直上位にある砂質土（崩積土）中の地下

表一 5 回復せん断歪み速度と経過時間との関係(山口県)

Table 5 Relationships of velocity of recoverable shearing strain versus lapse time (Yamaguchi Pref.)

\begin{tabular}{|c|c|}
\hline $\begin{array}{c}\mathrm{d} \gamma / \mathrm{dt} \\
\times 10^{-3}\left(\mathrm{day}^{-1}\right)\end{array}$ & $\begin{array}{c}\mathrm{t} \\
\text { (day) }\end{array}$ \\
\hline 0.875 & $0 \sim 4$ \\
\hline 0.700 & $4 \sim 6$ \\
\hline 0.550 & $6 \sim 9$ \\
\hline 0.350 & $9 \sim 13$ \\
\hline 0.135 & $13 \sim 16$ \\
\hline 0.120 & $16 \sim 25$ \\
\hline 0.050 & $25 \sim 35$ \\
\hline-- & $35 \sim 39$ \\
\hline 0.028 & $39 \sim 75$ \\
\hline
\end{tabular}

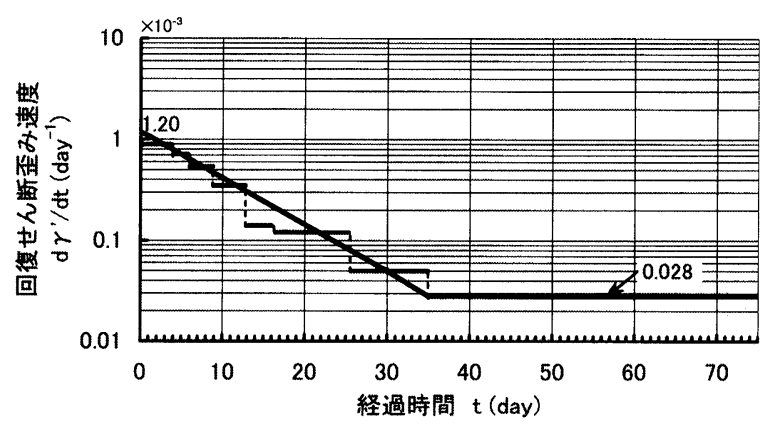

図一19 回復せん断歪み速度 $d \gamma^{\prime} / d t$ の時間的変化 (山口県美祢市)

Fig. 19 Relation between velocity of shearing strain(recovery) and time proceeds (Yamaguchi Pref.) 
水位が降雨によって上昇，または排水によって低下する ことによっておこる。これによって砂質土は不飽和状態 から飽和状態に，逆に飽和状態から不飽和状態になるた め含水比が変化する。

一方, 式(7)と図-9は 9 -wの関係であり, 同一の粘 性土においても粘性係数は含水比によって変化すること を示している。地下水位の変化に伴ってレオロジー挙動 する飽和粘性土の含水比がどのように変化するのか重要 な問題である。

室内実験などの結果によると，粘性土が吸水膨張して 含水比が増加する条件は次の場合がある2)。

(1) 土かぶり応力（上載応力）がほとんどないとき”。

(2) 粘性土中にスメクタイトのような吸水膨張性の粘 土鉱物が含有されるとき。

(3) 乾燥など直接大気の作用を受けるとき。

(4) 機械的な攪乱作用をうけるとき。

今回対象とした粘性土は(1)〜(4)の何れの条件にも該当 せず，吸水膨張による含水比の增加（または圧密による 含水比の減少）は発生しないのでクの值に変化はない。

これを実証するため現地粘性土の圧密試験を行ったが,

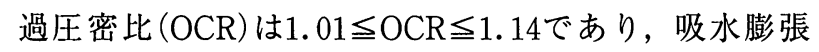
はおこっていないことを示唆している。

\section{3 粘性土の粘性流動挙動}

図一19によると，せん断歪みの回復が測定されておよ そ35日後から，1 ケ月以上にわたってせん断歪みの回復 速度が $0.028\left(\right.$ day $\left.^{-1}\right)$ の微小なものが持続している。こ の現象はVoigt modelでは説明できない。

室内実験ではある時間内のせん断歪みとの時間変化が 図ー20のように流動状態になる例が測定されている8

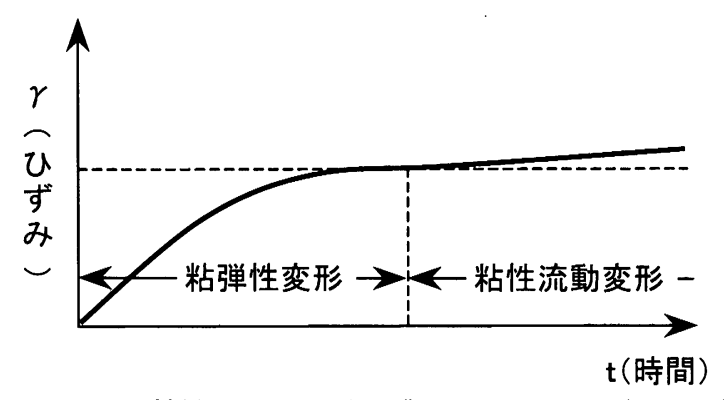

図一20 粘性土のせん断ひずみの時間的変化(模式図)

Fig. 20 Relation between shear strain of clayey soil and lapse time (a type fig.)

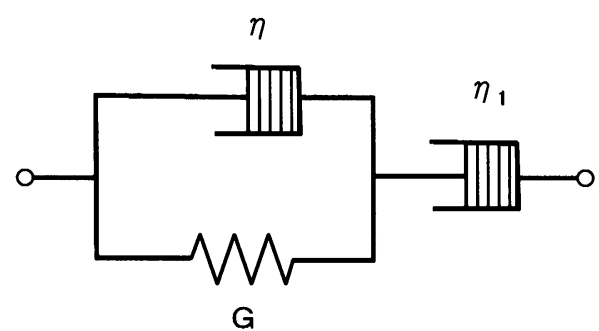

図ー21粘弾性変形と粘性流動とのレオロジーモデル

Fig. 21 Rheological model of viscoelastic and flow deformation
このレオロジー挙動のモデルは図-21で示される。すな わちVoigt modelにダッシュポットを直列に加えた模型 である。これに一定のせん断応力 $\tau_{0}$ を加えたとき（ま たは除荷したとき), せん断歪みとは,

$$
r=\tau_{0} / G\{1-\exp (-G \cdot t / \eta)\}+\tau_{0}\left(t-t_{1}\right) / \eta_{1}
$$

で表される。これがせん断歪みの時間的変化の理論式に なる。式(20)は右辺第 2 項のダッシュポットの流動変形が, 経過時間 $t_{1}$ から開始されるとした式である。この地内で 観測されたせん断歪みの回復速度は，

$$
\begin{aligned}
& d r^{\prime} / d t=0.028 / 1000=2.8 \times 10^{-5} \quad\left[\mathrm{day}^{-1}\right] \\
& \left(=3.24 \times 10^{-10}\right) \quad\left[\mathrm{s}^{-1}\right]
\end{aligned}
$$

である。この時（経過時間 $t_{1}$ において）式(20)の右辺第 1 項のせん断歪み速度は無視できるので, 右辺第 2 項を時 間 $t$ について微分すると，

$$
d \gamma^{\prime} / d t=\tau_{0} / \eta_{1}
$$

これからダッシュポットの粘性流動が, 応力減少 $\tau_{0}$ $=1.5 \mathrm{kN} / \mathrm{m}^{2}$ の条件で継続すると考えると, 粘性係数 $\eta_{1}$ は次のように計算される。

$$
\eta_{1}=1.50 / 3.24 \times 10^{-10}=4.63 \times 10^{9} \mathrm{kN} \cdot \mathrm{s} / \mathrm{m}^{2}
$$

これはさきに計算したクに比較すると 1 桁大きい值に なっており, せん断歪み回復過程における流動変形は微 小なものになる。なお，この傾向は図-17のせん断歪み 増加過程でも見られるが，これについては測定時間の間 隔が 9 ケとと長いため（測定值(5)以降について） $\eta_{1}$ を測 定値から計算することができない。

また, 回復せん断歪みとには最初から微小な粘性流動 の要因が入っているとして, 室内実験のように,

$$
r=\tau_{0} / G\{1-\exp (-G \cdot t / \eta)\}+\tau_{0} \cdot t / \eta_{1}
$$

の形式になれば，式(20)の $t_{1}$ (機構説明が難しい) は不要 である。多くの測定例を調べたが, 測定中断または測定 間隔が長く, 現場測定結果からは式(22)は確認されていな い。しかし式(21)のレオロジー挙動が見られることは, 粘 性土の挙動がVoigt modelだけの単純なものでないこと を示唆する。

\section{7. 粘性土斜面のレオロジー挙動}

図一22は，大分県下で頁岩風化層を基盤とする図 -23 の斜面（地層平均傾斜 $30^{\circ}$ ) に設置された孔内傾斜計の 測定例であり,このタイプの変状形態を示す観測例は多 い。平常時地下水位は $1.2 \mathrm{~m}$ と高く, 斜面内からは涌水 が見られ, 家屋基礎には平均幅 $6 \mathrm{~mm}$ の引張亀裂があっ て動態観測の必要がある地内である。ここは軟弱な残積 性粘土層が累層構造をしているために, 地層全体が図一 24の模式図のようなせん断変形をしていると考えられる。 このような変形が地層内で発生する機構と条件を粘性土 
のレオロジー挙動の観点から検討する。

この地内では 6 月17〜27日の間, 累計降雨量 $161 \mathrm{~mm}$ （日最大降雨量 $44 \mathrm{~mm}$ ) が記録されているが変位量はな い。6月28日，日降雨量 $81 \mathrm{~mm} に よ っ て ， 7$ 月20日に， 厚さ $10 \mathrm{~m}$ 間の範囲で, 地表面に $0.015 \mathrm{~m}$ 程度の変位量が 測定されているので，せん断歪み $\gamma$ は， $\gamma=1.5 \times 10^{-3}$ で ある。このせん断歪み $\gamma$ 時間変化が式(11)のVoigt model で表されると仮定する。6月28日を起点にして7月20日 の時間を $t \rightarrow \infty$ とすれば,

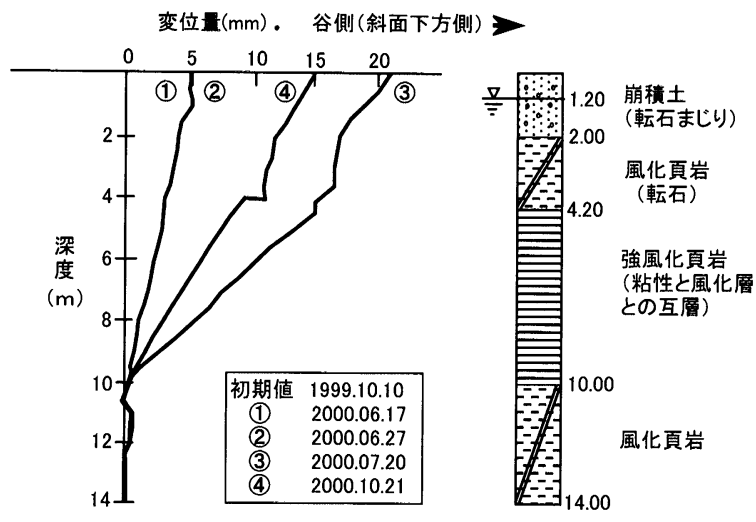

図一22 孔内傾斜計による変位量曲線 (大分県)

Fig. 22 Measurement of displacement of clayey layer used tiltmeter within the hole(Oita Pref.)

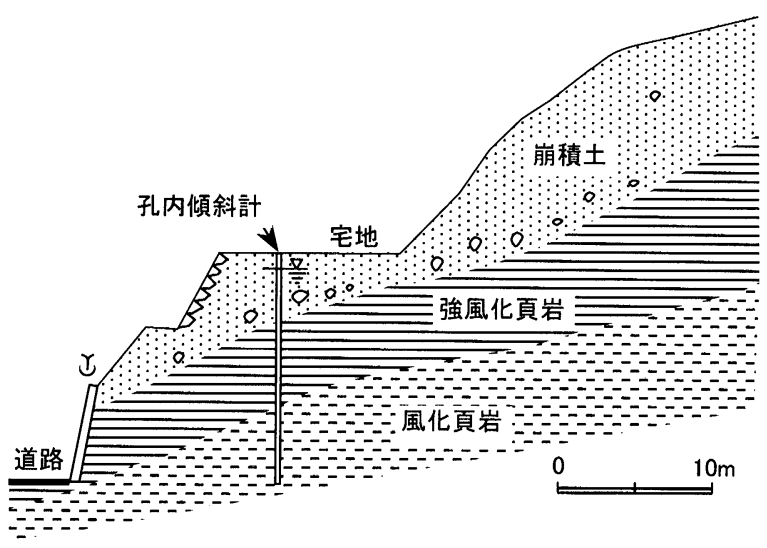

図一23 孔内傾斜計設置付近の地層断面図 (大分県)

Fig. 23 Geological section near the tiltmeter within the hole(Oita Pref.)

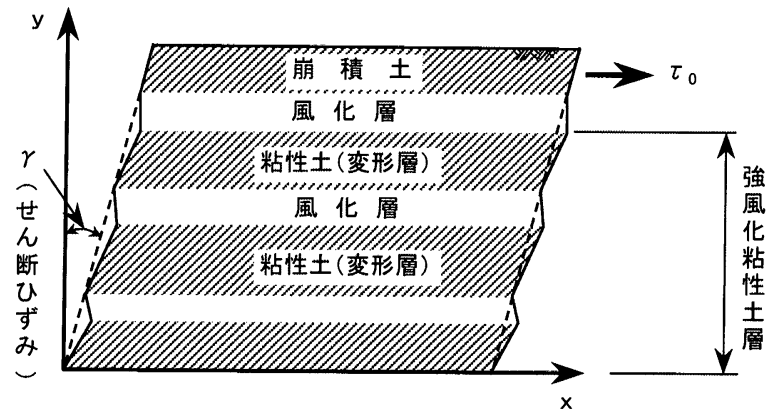

図一24粘性土斜面の粘弾性変形模式図(大分県)

Fig. 24 A type figure of viscoelastic deformation in the clayey layer(Oita Pref.)

$$
\gamma=\tau_{0} / G
$$

(23)

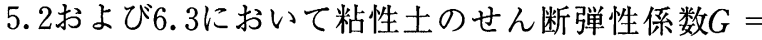
131〜 $144 \mathrm{kN} / \mathrm{m}^{2}$ が得られたが，図－24のように風化部分 を含む全層に対してはこの数值は小さい。上限降伏值以 下のせん断応力のもとでのクリープせん断試験の結果か ら得られる数值を参考にすると ${ }^{5)}, G=500 \mathrm{kN} / \mathrm{m}^{2}$ が妥当 である。

式(23)から，地表面に作用するせん断応力 $\tau_{0}$ は,

$$
\tau_{0}=G \gamma=500 \cdot 1.5 \times 10^{-3}=0.75 \mathrm{kN} / \mathrm{m}^{2}
$$

であるから必要な増加斜方分力 $W$ は,

$$
W=\tau_{0} / \sin \theta=0.75 / \sin 30^{\circ}=1.50 \mathrm{kN} / \mathrm{m}^{2}
$$

になる。これは地表面 $1 \mathrm{~m}$ 間の粘性土の単位体積重量が, 降雨によって不飽和から飽和になった重量増加に相当し, これはさきの例で使用した $\gamma_{s a t}-\gamma_{t}=18.25-16.56=1.69$ $\mathrm{kN} / \mathrm{m}^{3}$ にほぼ該当する。このことから図ー 22 タイプの粘 弾性挙動の原動力は，地表部飽和によるせん断応力（斜 方分力）の増加である。これには降雨浸透すなわち湿潤 面の下降と飽和状態の持続時間が条件で，降雨量と雨の 降り方が関係する ${ }^{3)}$ 。地下水位が低下して, 地表面付近 が不飽和状態になると, せん断応力 $\tau_{0}$ の減少に伴いVoigt modelのスプリング要因によってせん断歪みの回復現象 が現われている（図-22(4)）。過去，このような変状の 繰り返しと, 地層の受働抵抗が小さい傾斜地形が家屋基 礎の亀裂を発生させたものと考える。その後, 家屋基礎 の亀裂は拡大していない。

\section{8. 疑似地すべりに対する対応}

\section{1 疑似地すべりの調査}

表ー 2 に示したように，地すべりと疑似地すべりとの 構造的な差異は, 前者には潜在すべり面が存在し, ここ に連続したクリープせん断破壊面が形成されることであ る。

変状に対する探査は現状では試錐が主流であるが，こ れは以前から行なわれているため，疑似地すべりも念頭 に置いた探査の問題点についてのみ述べる。

(1) 変状が見られる地内でオールコア一方式の試錐を実 施した際に，粘性土の深度と層厚および含水比を測定， 粘性土の流動曲線（液性限界試験）を求める。これに よって粘性土の含水比から，図－9などを用いて粘性 係数の近似值を推定することができる。

(2) 試錐孔には孔内傾斜計を設置する。この測定は雨期 を挟んで長期間にわたるため，またリアルタイムの測 定值が解析結果になるので，地下水位観測を含めて自 動観測等にすることが望まれる。なお測定の結果，変 状が新規地すべりの兆候を示す場合の対策としては, 弱面探査等を実施することになるが，これらについて は以前に発表したことがあるので9省略する。 


\section{2 疑似地すべりの対策}

疑似地すべりは, 崩積土中の粘性土の粘弾性変形が原 因である。せん断応力の原動力は降雨による地層の飽和 であり，部分変形のため広範囲の地すべり面に発達する ことはない。このため従来の地すべり対策とは基本的に 異なり，主として下記の事項を検討する程度で差し支え ないと思われる。

（1）粘性土が粘弾性変形を繰り返したとき，深度が浅く スメクタイトのような粘土鉱物が含まれると吸水膨張 が進行することがある。これによってせん断弾性係数 と粘性係数とが低下すると, 流動が継続するクリープ 性地すべりと呼称される形態を示したり, 表層崩壊(地 すべりと区別する定義はないが）が発生することがあ るので，主として地表面付近の地下水位の上昇(飽和） を抑制する排水工法を検討する。また排水工事によっ て粘性土層以下に地下水位が低下し続けると, 粘性土 の圧密作用でこれの含水比が低下する。これによって

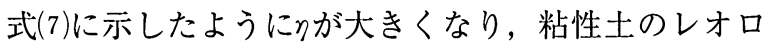
ジー挙動がおこり難くなる。現にこれらしき現象と思 える地内がある。

（2）崩積土のせん断歪みに起因する変位によって，先端 開放地形にある石積み擁壁の押し出し, コンクリート 擁壁のジョイントのズレ変位および天端部分の変状が 発生することがあるが，粘性土内を通る連続した地す ベり面は存在せず，地すべり推力は存在しないので抑 止力を主体とした防止対策の計画と施工は不要である。

\section{9.あとがき}

本論文は，地表面に現われる引張亀裂などの変状が， 地すべりに発展するものと，そうでない疑似地すべりの 場合の差異と特性および, 変状は必ずしも新規地すべり の前兆にはならないこと, さらに疑似地すべりの原動力 が地表面付近の飽和であることを現地観測に基づいて述 ベた。

変状に対志することは重要であるが，以上の理由から 防止工事を計画する以前に動態および地下水位観測を行 なって検討し, 変状の機構と実態の把握を行なうことが 重要である。最近の社会・経済情勢から, 変状に対して
は有効かつ最小限の対策費用で対処することが求められ ている。 本論文は疑似地すべりの発生機構を，崩積土中に含有 される粘性土のレオロジー挙動の観点から考察したが, 下記の問題点が残されており，同時に今後の課題である。

（1）粘性土の室内での二種類の粘性係数の測定法は，一 長一短があり崩積土の粘性係数を高精度で簡単に測定 するには難点がある。これ以外に一軸圧縮方式の測定 法も発表されているが10)，今まで特に必要とされな かった粘性土のせん断弾性係数と粘性係数測定は必要 であり，新規の測定法を検討する必要がある。

（2）本論文で使用した現地測定結果は，当初から粘性土 の粘弾性挙動を意識したものではなく測定時間間隔も 一定ではないため, せん断弾性係数と粘性係数とを厳 密に計算するには多少の無理がある。今後は現地にお いても計画的に, 精度の高い粘性土のレオロジー挙動 を測定する必要がある。

\section{参考文献}

1）玉田文吾 (1996)：講座・地すべりの予知と予防（その 3), 地すべり技術, Vol.22, No.3, pp. 19-24.

2 ）玉田文吾（1973）：第三紀地スベリの発生機構について，土と 基礎，Vol.21，No.7, pp. 33-39.

3 ）玉田文吾 (2003): 有効先行降雨量と崖崩れ表首崩壊との関係, 豪雨時の斜面崩壊のメカニズムおよび危険度予知に関するシ ンポジウム, 地盤工学会, pp. $49-58$.

4 ）玉田文吾（1975）：一軸圧縮試験方式よる地すべり面の粘性係 数測定, 第20回土質工学シンポジウム講演集, 土質工学会, pp. $175-178$.

5 ）玉田文吾, 保永雄二（1976）：粘性土のクリープ特性とその応 用, 西日本工業大学紀要, Vol. 6, pp. 39-46.

6 ）田中盛正, 鶴田和成（2000：コールドロン内の崩壊性地すべ りについて，九州の地すべり一予知予防について一，日本地 すべり学会九州支部, pp. 169-182.

7 ）玉田文吾（1969）：長崎県北松地区における地すべり発生機構 の特性, 地すべり, Vol.6, No. 1, pp. 23-24.

8 ）玉田文吾 (1980)：再滑動型地すべり面の $c, \phi$ とその変化, 地すべり, Vol.17, No.2, pp.10-19.

9 ）玉田文吾, 福田順二 (1994)：弱面探査による新規地すべりの 予知, 地すべり, Vol.33, No.1, pp. 44-52.

10）駒村富士弥（1966）：粘弾性理論による地すべり運動の解析, 地すべり, Vol.2, No.2, pp.1-5.

（原稿受付2003年 5 月19日，原稿受理2003年11月 4 日） 